\title{
DOI 10.26886/2520-7474.6(44)2020.13
}

UDC: $37.07: 378$

\section{FEATURES OF THE DEVELOPMENT OF THE GENERAL EDUCATIONAL INSTITUTION IMAGE}

\section{Usatenko \\ https://orcid.org//0000-0003-3125-1622}

e-mail: usatenkovera5@gmail.com

Kremenchug Pedagogical School A. S. Makarenko, Ukraine, Kremenchug

The article deals with the scholars' views on the development of the image of general educational institutions and defines the components and features of the development of the image of a modern general educational institution in the context of the transition of general secondary education to market relations. The author has identified the factors influencing the image of a general educational institution and outlines the directions of its development.

Key words: image, image of general educational institution, image development of general educational institution.

Problem statement. At the present stage of the reform of the State educational system, the processes taking place in general secondary education are of particular importance. Practical implementation of the Concept «New Ukrainian School» for the period 2029 (2016), adopted by the Law of Ukraine «On Education» (2017) the principles of equal opportunities of access to quality education for all, humanocentrism, rule of law, transparency and publicity in the adoption and implementation of management decisions, integration with the labour market, inseparable links with world and national history, culture, national traditions (and others) [1] Require the management of general educational institutions to respond 
adequately and flexibly to changes in the external and internal educational environment. These factors have led to an increase in the role of the organizational culture of general educational institutions (hereinafter referred to as the GEI) and its image in increasing competitiveness in the market of educational services.

Thus, the research of the development of the image of a general secondary school is relevant and useful.

Literary review. Management of the development of organizational culture, including institutions of general secondary education, is situated in the circle of scientific interests of domestic and foreign scientists, such as $L$. Vasylchenko, G. Yelnykova, A. Zhukovska, L. Kalinina, V. Lugovyi, V. Maslov, N. Ostroverkhova, Ye. Rudniev, D. Serkis, Ye. Smirnov, H. Tymoshko, K. Ushakov.

Positive changes in the organizational culture of GEI are being ensured by the development of its image. A. Bandurka, O. Zemlyanska, L. Aleksieieva, A. Gromov, V. Shpalinskyi considered the general psychological foundations of the image of educational institutions. Problems of interdependence of management and image of modern school are reflected in works of S. Starobynskyi, B. Andryushkin, V. Yatsura, S. Skibynskyi, F. Khmil, A. Ilyin. Various aspects of the work of the head of image creation are discussed in the studies of G. Pocheptzov, Ye.Utkin, O. Omarova, O. Felser, O. Dobronevskyi. M. Fadeyev researched the technologies of the formation of a positive image of the general educational institution. Problems of image assessment of the GEI were highlighted in the studies of I. Posohova and A. Kazanicher.

The purpose of the article is to reveal the features of the development of the image of general secondary education as a significant factor in increasing its competitiveness on the educational services market. 
Presentation of the main material. The organizational culture of general secondary educational institution takes place over time, absorbing the experience of the employees, taking into account the aims and orientations of the organization. The overall purpose of the organizational culture (hereinafter referred to as $\mathrm{OC}$ ) is to create a healthy psychological climate in the organizations in order to unite the staff into a collective that upholds certain ethical, moral and cultural values.

Factors influencing the development of the GEI OC:

- External: characteristics of the political and economic situation in the State; general culture of society, region and micro-society; level of development of scientific and technological progress; changes in educational legislation and educational reforms; organizational culture of other educational institutions and the culture of the educational administration; the needs and requirements of educational services users;

- Internal: the age of the GEI (its duration) of organizational values; the nature of the traditional $\mathrm{OC}$; the success of the educational institution; the appointment, mission of the general educational institution; the cohesiveness of the general school team in carrying out the mission; innovative processes in the GEI management and operation;

- Personal: the personality of the leader, creativity in making management decisions and ways of implementation, innovative management thinking; personal qualities of the management team, creativity in solving problems encountered during the educational process; teachers' personal values, goals, needs, rules and principles, their ability to create an atmosphere of mutual understanding and mutual support, and to instil in pupils and their parents a sense of belonging to a single school family. 
The organizational culture performs various functions, namely: security, integration, regulation, adaptive, guidance, motivation, creation and development of the GEI image [2].

While the researching the image structure of the GEI, scientists focus on two of its components: external (architectural attractiveness, aesthetic design of premises, symbols, traditions, style of clothing, social activity of participants in the educational process, support and encouragement of creativity, social orientation of projects implemented by the team, presentation of GEI) and internal (the degree to which the sociopsychological climate in the GEI community is favourable, the introduction of innovative management and pedagogical technologies and the improvement of the professional skills of teaching staff, management culture of the head and management team, pedagogical culture of teachers, level of applicants for education) [8].

From another point of view, the image of a modern GEI has two meanings: the information - formed in the consciousness of society the GEI image and the evaluation, which consists of a qualitative assessment by the public of the educational activities organization and its results.

The image of GEI is the image created in the mass consciousness of an emotionally coloured image, which determines the level of different educational activities organization and the relationship between them, actively maintained internally and disseminated externally [4].

The value nature of image has to be determined.

The image of the GEI is developed on the basis of the system of organizational values that has been developed. The image takes into account material and spiritual artifacts of importance to the participants in the educational process, and traditions, generally accepted norms and rules of conduct in the GEI. The most effective image will be that which resonates 
in the basic values of society, that is the values of ordinary consciousness and behavioral manifestations.

Through education multientity the image should represent a reasonable compromise between the values of the different categories of participants in the educational process and the balance between them. The difficulty in forming an image from this point of view lies in the fact that harmonization requires the determination of the values of a wide range of actors, including: teaching staff members, applicants for general education and their parents, the media, public organizations and other users of educational services.

The image of the GEI does not merely reflect the values of subjects and objects, but also contributes to the development of new organizational values in accordance with changes in the internal and external educational environments, can only be seen in the case of: if the elements of the image are confirmed by the performance of the GEl.

The image of general secondary education is not limited to the value system. Through and without it, it applies to social norms represented by law, morals, customs and traditions, which are often at odds with each other. Thus, through values and norms, image has a significant impact on almost all educational process participants. At the same time, it is also a significant instrument for the social management of the GEldevelopment.

The positive image of general educational institution is being developed in two interrelated ways:

- $\quad$ improvement of the conditions and introduction of innovations in the educational process organization (internal image)

- $\quad$ active cooperation with the public (external image) [6].

Therefore the school administration is faced with the challenge of mobilizing all external and internal resources to modernize the educational process, update all aspects of activity, find new solutions to known 
problems, generate fresh organizational ideas the implementation of which will inject new energy into the school life. It will provide a new impulse for the positive school image development.

V. Vasylenko believe that the development of the general educational institution image [3], it can be argued that one of the key factors for the success of this process is the image of its leader, management team, pedagogical, student and parental staff.

According to R.Lysenko, the transition to market relations in general education requires the leaders of the GEI to systematically improve their academic and professional level [5]. Principals of schools have not only to perform their functions as a manager, but also to make active use of the managerial potential of the organizational culture by developing their own image and that of their educational institution.

The image of the GEI is evaluated according to the following indicators: essential characteristics of the image of the GEI; compliance with the criteria "positive-negative», "clear-fuzzy»; time of the existence of the image; material costs of creating and maintaining image, economic indicators; efficiency of image formation process; expressiveness and sustainability of image.

I. Kabardynska represents the following essential features of the image:

1. Relevance of image to achieve an objective.

2. Projectiveness of image: compliance of image with the criteria of practical management, that is, ability to plan, organize, manage, control; credibility of image - ensuring the performance of its purpose with the least risk; recognition of image - the information received is linked to the organization in the public consciousness.

3. Reflection of the general, explicit and hidden public needs in image.

4. Trust to the image [5]. 
Consider the structure of the image of the GEI (table 1).

\section{Image structure of general educational institution}

\begin{tabular}{|l|l|}
\hline & The public perception of the educational services provided \\
by the GEI is based on the following criteria: \\
Demand for educational services; \\
Price/quality ratio of additional education services; \\
The uniqueness of offers is the absence of analogues in \\
the market of educational services. \\
Image of
\end{tabular}


In order to properly shape the image, the leader must provide information from the first-hand side to conduct as many public speeches as possible, to give interviews, to comment on events, to avoid any positive informational cause.

The employee image is the collective generalized image of the team of the GEI, revealing the most characteristic features, professional and personal qualities. However, it is formed primarily through direct contact with a certain Employee image representative. At the same time, each employee is considered as a "person» of the GEI on which will form opinion about the collective as a whole. Therefore, it is important to take care of the moral, intellectual, informational, speech culture of every employee, regardless of the position they hold or the work they do.

Internal image

Organizational culture;

Favourable psychological microclimate in the GEI.

Visual image is one of the main means of creating the image of the GEl.

Visual image

External ideas about the GEl are influenced by such factors as: exterior; interior; organizational style.

A social image is the perception of the environment of

Social image social goals and the role of GEI in public life.

The mission of the GEI is a social reason for it being its business card.

Business image or reputation is created in cooperation Business image with business partners and is achieved through:

Stability of work; 
Transparency in cooperation with partners;

Commitment etc.

The formation and management of the image of GEI is a purposeful, scientifically balanced process. The problem of forming an image is the problem of psychological and pedagogical, cognitive and emotional, rational and artistic means of creating a positive image of the GEI, and the reflection in this image of internal, substantive meanings, content and tasks, features of educational activity.

In order to ensure the scientific soundness of the development management of a positive image of the GEl it is necessary to implement the following principles (table 2).

Table 2

\section{Principles of managing the of a positive image development} of the general educational institution

\begin{tabular}{|l|l|}
\hline Principle of national orientation & $\begin{array}{l}\text { - The construction of education taking } \\
\text { into account the history and folk } \\
\text { enrichment of the culture of the Ukrainian } \\
\text { people and other peoples living in the } \\
\text { territory of Ukraine and the formation of } \\
\text { national consciousness }\end{array}$ \\
\hline Principle of learning openness & $\begin{array}{l}\text { - Orientation of education towards a } \\
\text { holistic pedagogical world, its global } \\
\text { of universal values over group and class } \\
\text { values, integration into international } \\
\text { educational, social and cultural systems }\end{array}$ \\
\hline Principle of humanity & - Affirmation of the human being as the \\
& highest social value, creation of \\
\hline
\end{tabular}




\begin{tabular}{|c|c|}
\hline & $\begin{array}{l}\text { conditions for taking into account the } \\
\text { different needs, interests and values of } \\
\text { teachers and children, and taking into } \\
\text { account their individual and psychological } \\
\text { characteristics in the organization of } \\
\text { management and educational activities }\end{array}$ \\
\hline Principle of democracy & $\begin{array}{l}\text { - Creation of conditions for the active } \\
\text { participation of teachers and students in } \\
\text { solving current problems in the GEI } \\
\text { activity and in organizing the teaching and } \\
\text { educational process on the basis of a } \\
\text { partnership between teachers and pupils }\end{array}$ \\
\hline Principle of stimulating learning & $\begin{array}{l}\text { - Intensive acquisition of knowledge, } \\
\text { skills for acquiring new knowledge, } \\
\text { positive motivation for learning and } \\
\text { cognitive activities }\end{array}$ \\
\hline $\begin{array}{l}\text { Principle of creative potential } \\
\text { formation }\end{array}$ & $\begin{array}{l}\text { - Development of skills to pose new } \\
\text { problems, both at the theoretical and } \\
\text { practical levels, to find alternative } \\
\text { solutions, to develop the flexibility of } \\
\text { thinking and the ability to adapt to social } \\
\text { changes }\end{array}$ \\
\hline $\begin{array}{l}\text { Principle of unity of education } \\
\text { and upbringing }\end{array}$ & $\begin{array}{l}\text { - The organic combination of education, } \\
\text { upbringing and personal development, } \\
\text { and the orientation of education towards } \\
\text { the formation of a whole and } \\
\text { harmoniously developed personality. } \\
\text { Special forms of work for the } \\
\text { administration, teachers, students and }\end{array}$ \\
\hline
\end{tabular}


their parents help to create a positive image of GEIH

We believe that the main characteristics of the management of the image of a modern general educational institution are:

- the impact of innovative social transformations on the organization of the educational process;

- fundamental reform of the general educational system;

- regional characteristics of socio-economic development;

- instability of the demographic situation;

- increased competition in the market for educational services;

- complexity of the structure of the general school staff, which includes the pedagogical staff, including the head and management team, students and parents.

The principal and the management team play a leading role in the formation and developing the image of the school. They are the origins of organizational values, norms and rules of behaviour, school traditions, the creation of a favourable social and psychological climate, and the enhancement of the creative potential of the general school community.

The pedagogical team supports the introduction by the leadership of innovative organizational changes that facilitate the realization of the mission and the high-purpose school. Teachers ensure the provision of quality educational services, increase the impact of educational activities. They show interest in the personal development of each pupil, and establish partnerships with parents of pupils by the creation of the atmosphere in which everyone is involved in common affairs and develop the image of general educational institution as a highly professional educational institution. 
The formation and development of a positive image of a leader and an educator begins with the establishment of a style of communication that would help all participants in the educational process to perform their functions in a quality, comforting manner in the collective, to involve the parents' community in the creative cooperation.

The role of the parent community in formation and developing a positive image of the school is very important, as it is they who not only lead their children to a specific GEI. They also estimate the work of the school. By permanently spreading in society, this assessment shapes public opinion, creates its authority and develops its image. Parents are the main target group to which the principal and the pedagogical team orient in developing their image, and the main investors of school image policy.

The examination of the opinion of parents of pupils on the state of educational activity of the El helps the head to respond to their requests promptly, to view and create the optimal mode of interaction, to organize close and effective cooperation between three constituent groups of the general school community and promote the development of the school's image and organizational culture.

The students' opinion of the home school is equally important, as it is they who provide information about the school to their peers and their parents; who give an impression of the day-to-day life of the school via the Internet; and who demonstrate the quality of their education in public places; graduates - chief «PR» of their school [7].

Traditional festivals and school-wide events are aimed at rallying the student community. School symbols and attributes and the involvement of student self-management in the realization of the school's mission contribute to the development of love for the home school and respect for all participants of the educational process. 
The results of the activities of the head and the pedagogical team for the development of positive image of the El are improved by an active PR campaign, which includes the following elements: promotion of the achievements of the pedagogical and student groups; involvement of the mass media in the advertising campaign; advertising booklets, business cards, school symbols and attributes; holding of events at the educational establishment at the city and the regional levels.

Conclusions. The formation and development of the image of a general educational institution is a complex, ambiguous and long-term process that requires a combination of the creative potential and efforts of the school's teaching, student and parent groups, their perseverance and determination, inspiration. The originality and uniqueness of the organizational culture of general educational institution is enhanced by the positive opinion of the public about its leader, the teaching staff, the achievements of the students, which are the part of a positive image, which affects the improvement of competitiveness in the educational services market.

\section{References:}

1. Law of Ukraine «On education» from 05.09.2017 2145-VIII» URL: http://zakon2.radgov.ua/laws/show/214519/

2. Andriienko N. (2018) Formation of the positive image of the educational institution. Psychologist. Series "The school world». 2018. 5/6 (February). 4-11.

3. Vasylenko $\mathrm{V}$. The current state of research into the process of formation of the image of higher education: a theoretical aspect. Karazin Kharkiv National University Edition. Series «Social Communication».Vol. 13. 2018. 20-27. 
4. Vozniuk V. (2016) Positive image of the educational institution and management culture of its head. Pedagogical search. Vol. 2. 12-16.

5. Lysenko G.(2011) Means of creating a positive image of the educational institution. Pedagogical workshop. Vol. 8. 7-9.

6. Marmaza A. (2009) Exploiting the potential of image management in educational institutions. School management. Vol. 19-21. 55-59.

7. Usatenko V.M. (2017) Analysis of organizational culture development management as a substrate of prediction of positive image of general educational institution. Sciencerise: Agogpedical Education. Kharkiv: SPE «Technological Center». Vol. 1(9). 41-45

Citation: V. Usatenko (2020). FEATURES OF THE DEVELOPMENT OF THE GENERAL EDUCATIONAL INSTITUTION IMAGE. Frankfurt. TK Meganom LLC. Paradigm of knowledge. 6(44). doi: 10.26886/2520$7474.6(44) 2020.13$

Copyright V. Usatenko $\odot$. 2020. This is an openaccess article distributed under the terms of the Creative Commons Attribution License (CC BY). The use, distribution or reproduction in other forums is permitted, provided the original author(s) or licensor are credited and that the original publication in this journal is cited, in accordance with accepted academic practice. No use, distribution or reproduction is permitted which does not comply with these terms. 